\title{
Using digital panoramic radiographs to examine temporal styloid process elongation
}

\author{
Uso de radiografias panorâmicas digitais para examinar o alongamento do processo estilóide \\ temporal \\ Uso de radiografías panorámicas digitales para examinar el alargamiento de la apófisis estiloides
} temporal

\author{
Carlos Eduardo Nogueira Nunes \\ ORCID: https://orcid.org/0000-0003-4223-4633 \\ Federal University of Ceará, Brazil \\ E-mail: caduunogueiraa@gmail.com \\ Ana Cecília Carenina Machado Mourão \\ ORCID: https://orcid.org/0000-0002-8569-224X \\ Federal University of Ceará, Brazil \\ E-mail: anacarenina05@gmail.com \\ Filipe Nobre Chaves \\ ORCID: https://orcid.org/0000-0001-6345-8156 \\ Federal University of Ceará, Brazil \\ E-mail: filipenobrechaves@gmail.com \\ Denise Helen Imaculada Pereira de Oliveira \\ ORCID: https://orcid.org/0000-0001-6020-2374 \\ Federal University of Ceará, Brazil \\ E-mail: denisehelen2011@hotmail.com \\ Marcelo Bonifácio da Silva Sampieri \\ ORCID: https://orcid.org/0000-0001-7942-6642 \\ Federal University of Ceará, Brazil \\ E-mail: mar_sampieri@hotmail.com
}

\begin{abstract}
The styloid process of the temporal bone is a bone projection which is localized anteriorly to the stylomastoid foramen, in between the internal and external carotid arteries, and posteriorly to the pharynx The normal average length of the styloid process is 20 to $30 \mathrm{~mm}$. The aim of this study was to evaluate the average lengths of the styloid process in patients who underwent panoramic radiographs in a private clinic.A sample calculation was conducted to define the minimum size needed to represent the entire state of Ceará, Brazil. After establishing a confidence level of $95 \%$ and a $5 \%$ margin of error, a minimum of 385 panoramic radiographs was determined based. Following inclusion and exclusion criteria, at the end 503 panoramic radiographs were included. In order to evaluate the associations between styloid process lengths and gender/age. Elongated styloid process was found in $56 \%$ of the radiographies of male patients and in $41 \%$ of the ones of female patients. The mean average of styloid process length was $33.51 \mathrm{~mm}$ for male and $31.17 \mathrm{~mm}$ for female patients. The relationship between the length of the styloid process and age was significant only if the right side was considered. The inter and intra-examiner calibration was evaluated by the Kappa Test. The data normality of the errors was evaluated using the Shapiro-Wilk's Test. Then, the data were analyzed with ANOVA, Student's T-test and Chi-squared Test. Among all participants, 46.2\% exhibited elongated styloid processes based on their respective radiographs.
\end{abstract}

Keywords: Facial pain; Diagnostic imaging; Epidemiologic studies; Bone lengthening.

\section{Resumo}

O processo estiloide do osso temporal é uma projeção óssea localizada anteriormente ao forame estilomastoide, entre as artérias carótidas interna e externa e posteriormente à faringe. O comprimento médio normal do processo estiloide é de 20 a $30 \mathrm{~mm}$. O objetivo deste estudo foi avaliar os comprimentos médios do processo estiloide em pacientes submetidos a radiografias panorâmicas em uma clínica privada. Foi realizado um cálculo amostral para definir o tamanho mínimo necessário para representar todo o estado do Ceará, Brasil. Após estabelecer um nível de confiança de $95 \%$ e uma margem de erro de 5\%, foi determinado um mínimo de 385 radiografias panorâmicas. Seguindo os critérios de inclusão e exclusão, ao final foram incluídas 503 radiografias panorâmicas. A fim de avaliar as associações entre comprimentos de processos estilóides e sexo / idade. Processo estilóide alongado foi encontrado em 56\% das radiografias de pacientes do sexo masculino e $41 \%$ das do sexo feminino. A média do comprimento do processo estiloide foi de $33,51 \mathrm{~mm}$ para 
homens e 31,17 mm para mulheres. A relação entre o comprimento do processo estiloide e a idade foi significativa apenas se o lado direito for considerado. A calibração inter e intraexaminador foi avaliada pelo Teste Kappa. A normalidade dos dados dos erros foi avaliada por meio do Teste de Shapiro-Wilk. Em seguida, os dados foram analisados com ANOVA, teste t de Student e teste qui-quadrado. Entre todos os participantes, 46,2\% exibiram processos estilóides alongados com base em suas respectivas radiografias.

Palavras-chave: Dor facial; Diagnóstico por imagem; Estudos epidemiológicos; Alongamento ósseo.

\section{Resumen}

La apófisis estiloides del hueso temporal es una proyección ósea que se localiza anteriormente al agujero estilomastoideo, entre las arterias carótidas interna y externa y posteriormente a la faringe. La longitud promedio normal de la apófisis estiloides es de 20 a $30 \mathrm{~mm}$. El objetivo de este estudio fue evaluar las longitudes promedio de la apófisis estiloides en pacientes sometidos a radiografías panorámicas en una clínica privada; se realizó un cálculo de muestra para definir el tamaño mínimo necesario para representar todo el estado de Ceará, Brasil. Luego de establecer un nivel de confianza del $95 \%$ y un margen de error del 5\%, se determinó en base un mínimo de 385 radiografías panorámicas. Siguiendo los criterios de inclusión y exclusión, al final se incluyeron 503 radiografías panorámicas. Con el fin de evaluar las asociaciones entre la longitud de la apófisis estiloides y el sexo / edad. La apófisis estiloides alargada se encontró en el 56\% de las radiografías de los pacientes masculinos y en el $41 \%$ de las de las mujeres. El promedio de longitud de la apófisis estiloides fue de 33,51 mm para los hombres y 31,17 mm para las mujeres. La relación entre la longitud de la apófisis estiloides y la edad fue significativa sólo si se consideró el lado derecho. La calibración inter e intraexaminador se evaluó mediante la prueba Kappa. La normalidad de los datos de los errores se evaluó mediante la prueba de Shapiro-Wilk. Luego, los datos se analizaron con ANOVA, prueba T de Student y prueba de Chi-cuadrado. Entre todos los participantes, el 46,2\% exhibió procesos estiloides alargados según sus respectivas radiografías.

Palabras clave: Dolor facial; Diagnóstico por imagen; Estudios epidemiológicos; Alargamiento óseo.

\section{Introduction}

The styloid process of the temporal bone is a bony projection that is anteriorly localized to the stylomastoid foramen, in between the internal and external carotid arteries and posteriorly to the pharynx (Bruno et al., 2017; Alzarea et al., 2017; Pokhael et al., 2013; Gracco et al., 2017). The styloid process originates from the Reichert cartilage of the second pharyngeal arch (Bruno et al., 2017; Alzarea et al., 2017; Pokhael et al., 2013; Gracco et al., 2017). Normal average length for a styloid process is 20 to 30mm. As such, those measuring over 30mm are considered elongated ((Bruno et al., 2017; Alzarea et al., 2017; Gracco et al., 2017; Bodin et al., 2013). Elongated styloid processes or calcifications of ligament estilo-hiode are associated with symptoms of orofacial and cervical pain; such pains are typically worse when swallowing, opening the mouth, and/or rotating the head. These symptoms characterize Eagle syndrome (Bruno et al., 2017; Alzarea et al., 2017; Pokhael et al., 2013).

Due to its variable and unspecific symptomatology, Eagle syndrome may be confused with other conditions (Bodin et al., 2013; Scaf et al., 2005). To conclude such a diagnosis, clinicians must therefore be aware of possible differential diagnoses, such as glossopharyngeal and trigeminal neuralgia, temporal arteritis, migraine, histaminic cephalgia, myofascial dysfunction syndrome, cervical arthritis, temporomandibular joint disorders, and pharyngotonsillitis (Pokhael et al., 2013; Gracco et al., 2017).

Previous studies have demonstrated that styloid process length can be measured using conventional radiographs, such as those of the posterior-anterior projection of the mandible, lateral-oblique projection of the mandible, axial, and cephalometric (Alzarea et al., 2017). However, a 2019 systematic review suggested that digital panoramic radiograph images enable easier interpretations, expose patients to less radiation (when compared to computed 3D tomography), and are less costly (Bruno et al., 2019). As such, panoramic radiography is considered the most appropriate method for initially diagnosing changes to the styloid process and conducting related epidemiological research ((Bruno et al., 2017; Gracco et al., 2017; Bruno et al., 2019).

This study evaluated the prevalence of styloid process elongation among patients in Ceará, Brazil using digital panoramic radiographs. 


\section{Methodology}

The methodological approach of the current research is characterized as a cross-sectional study, according to Estrela et al (2018), which has the advantage of low cost, in addition to allowing the determination of the prevalence of a certain disease or anatomical pattern. In our research, the prevalence of elongation of the styloid process was evaluated by collecting quantitative data by measuring the length of the patients' styloid process through digital panoramic radiographs. According to Pereira et al., the set of numerical data collected allows an analysis to be carried out using statistical mathematical techniques, as was done in our study.

The study sample consisted of panoramic radiographs that were taken at a private clinic between 2018 and 2019 from male and female patients aged 18 to 80 years. All research methods were approved by the Ethics Committee (process 3.196.724). Further, informed consent was obtained from all patients prior to analysis.

A sample calculation was conducted to define the minimum size needed to represent the entire state of Ceará, Brazil. Here, data collected from the Brazilian Institute of Geography and Statistics (IBGE) revealed a total state population of 8,843,000 persons. After establishing a confidence level of $95 \%$ and a $5 \%$ margin of error, a minimum of 385 panoramic radiographs was determined based on this figure. To be included for analysis, all panoramic radiographs were required to present high-quality images of both styloid processes with low distortion, medium density and contrast levels, and no ghost images. Radiographs that did not meet these criteria were excluded from study.

\section{Image obtention}

All digital panoramic radiographs were obtained and analyzed using the CRANEX system developed by the SOREDEX company (Tuusula, Finland). Images were taken with parameters set to $73 \mathrm{kVp}$ and $10 \mathrm{~mA}$ for $17.6 \mathrm{~s}$ of exposure time.

\section{Image analysis}

The radiographic images were evaluated by two examiners experienced in radiographic management in an isolated manner and at two different times in order to make the intra-examiner and inter-examiner evaluation possible.The apparent length of each styloid process was measured using the tool available through the CRANEX software (Figure 1).

All radiographs were evaluated in a room with appropriate lighting. Styloid process length was measured on the frontal side of the bone process, from the origin of the tympanic plaque to the tip of the styloid process (Figure 1) (Bruno et al., 2017; Alzarea et al., 2017; Gracco et al., 2017). Styloid processes above $30 \mathrm{~mm}$ were classified as elongated as present in Figure 2a and classified as normal below $30 \mathrm{~mm}$ as present in Figure 2b. When then evaluated the associations between styloid process lengths and gender/age. As such, all radiographs were separated by gender and age according to the following criteria: Gender = male or female, while age (years) $=18-30,31-45$, or $>45$. Two trained researchers repeated all measurements one month after the first evaluation. 
Figure 1 - image capture of the CRANEX panoramic radiography system.

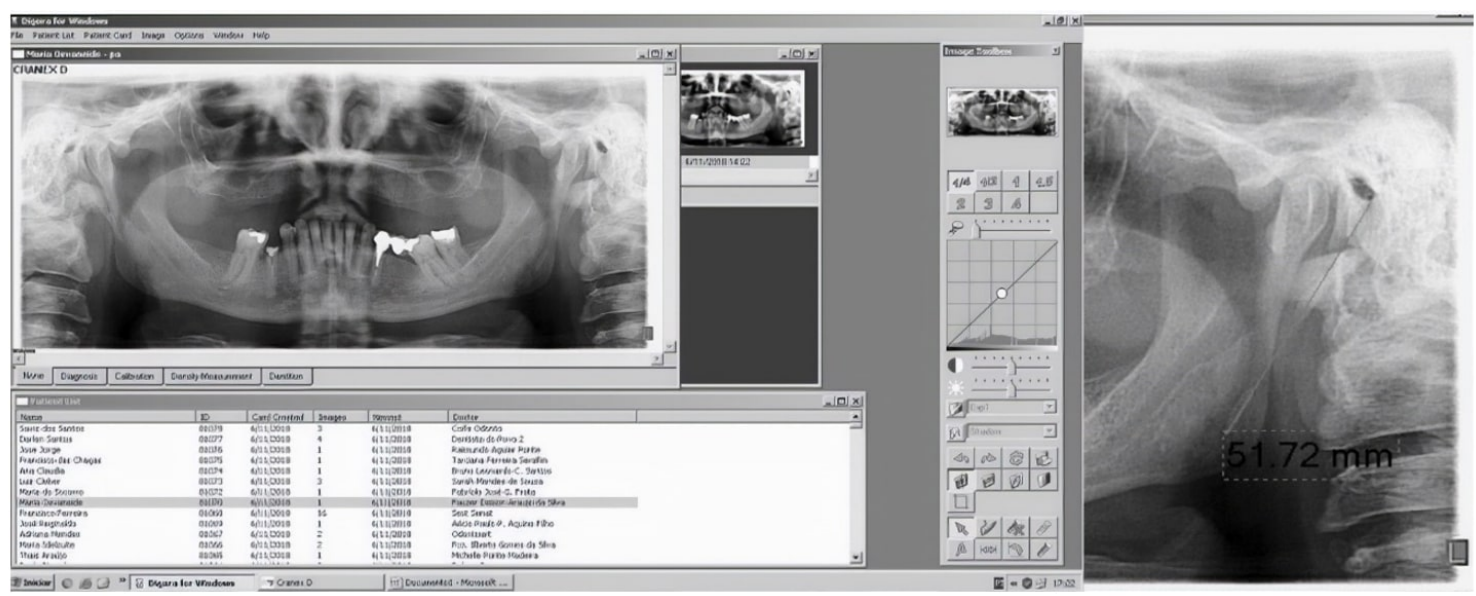

Source: Authors.

Figure 2a: left image shows an elongated styloid process $(68 \mathrm{~mm}), 2 \mathrm{~b}$ : in comparison with a normal length styloid process $(24$ $\mathrm{mm})$.

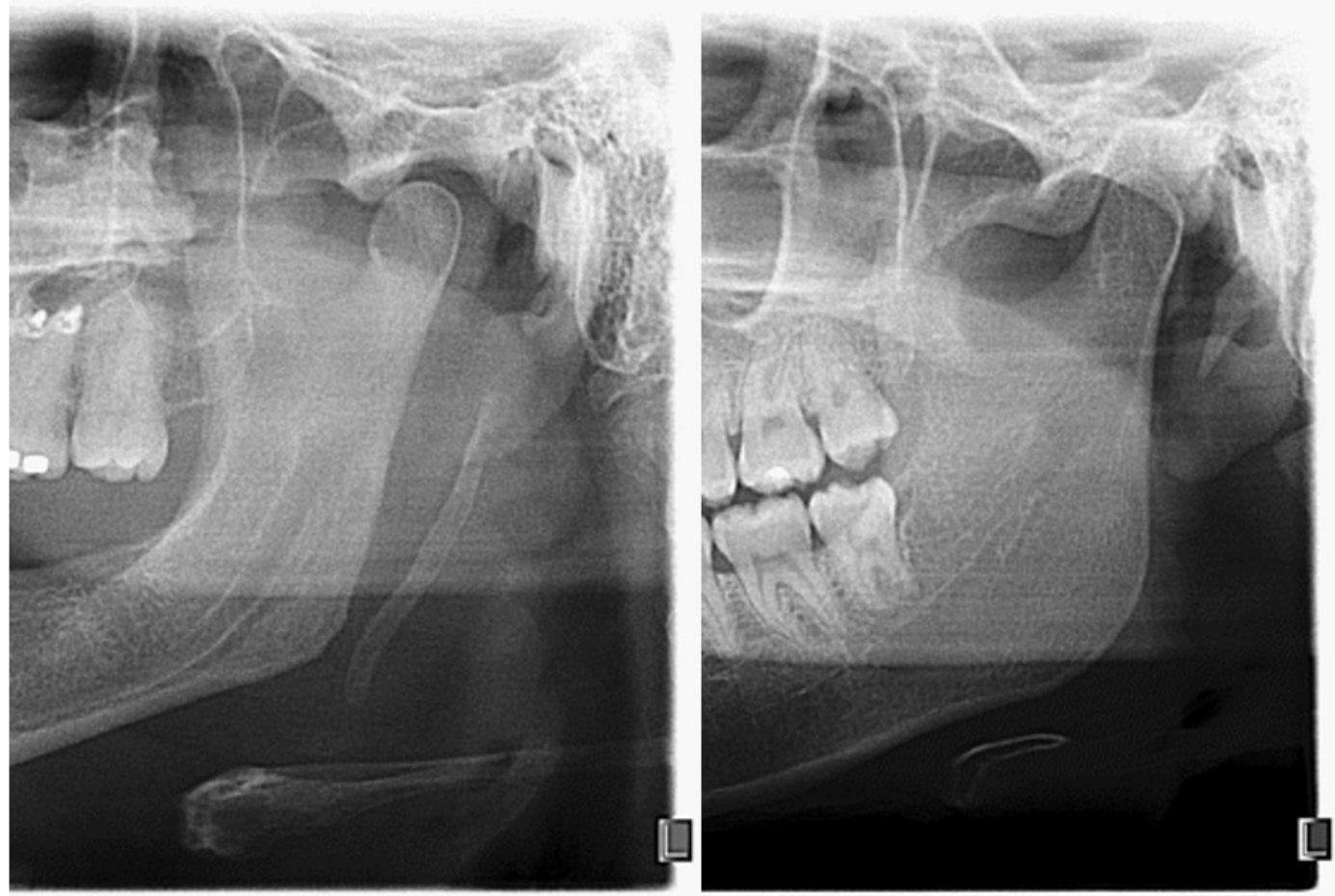

Source: Authors.

\section{Statistical analysis}

Inter and intra-examiner calibration was evaluated through a Kappa Test, which revealed values of 0.85 and 0.9 , respectively. Error normality was then evaluated through a Shapiro-Wilk's Test.

Through the Shapiro-wilk test, the presence of non-parametric data was evidenced, being necessary to carry out individual tests to compare data. This is in contrast to the possibility that the collected data will fit in paemetrics, making it possible to perform the multifunction ANOVA test to compare all the data simultaneously.

Next, data were analyzed through an ANOVA followed by a Tukey's test (Table 1) to evaluate whether there were any statistical differences in styloid process lengths according to the three abovementioned age groups. Finally, a Student's t-test 
(Table 2) was conducted to determine any general differences in styloid process lengths according to gender, while a chi-squared test (Table 3) was conducted to determine the prevalence of elongated styloid processes between genders.

\section{Results}

A total of 800 panoramic radiographs were evaluated for the inclusion criteria. However, only 503 were deemed suitable for analysis (see Material and Methods section). Patient ages ranged from 18 to 76 at the time their respective radiographs were taken. While 151 of these belonged to male patients, 352 belonged to female patients. As such, a total of 1,006 styloid processes were ultimately evaluated; no distinction was made between the left and right sides.

Table 1. Mean length of temporal styloid processes according to age.

\begin{tabular}{|c|c|c|c|c|c|}
\hline Temporal styloid & & Age (year & & & -Value \\
\hline$(\mathrm{mm})$ & $18-30$ & $31-45$ & $>45$ & TOTAL & \\
\hline Right side & $30.85 \pm 6.50$ & $32.75 \pm 8.34$ & $32.21 \pm 8.43$ & $31.75 \pm 7.62$ & $0.04098 *$ \\
\hline Left side & $31.30 \pm 6.76$ & $32.54 \pm 7.30$ & $32.67 \pm 8.13$ & $32.00 \pm 7.27$ & 0.21245 \\
\hline
\end{tabular}

*Statistical significance. Source: Authors.

Table 1 shows the analysis results according to age. As seen, the right and left (32.54mm and $32.75 \mathrm{~mm}$, respectively) styloid processes of patients aged 31 to 45 years were longer on average than those of patients aged 18 to 30 (31.30mm and $30.85 \mathrm{~mm}$, respectively). However, statistical differences were only significant in regard to right-side styloid process lengths. Moreover, no differences were found when comparing patients aged 31 to 45 years with those over 45 .

Further, the standard deviation of styloid process lengths among patients over 45 years of age was higher than those of the other age groups. For instance, 18 of the 113 total patients over 45 years of age had right styloid processes measuring more than $43.8 \mathrm{~mm}$ (15.9\%), while 14 had left styloid processes measuring more than $45.05 \mathrm{~mm}(12.4 \%)$. On the other hand, only 12 of the $232(5.2 \%)$ total patients aged 18 to 30 years had elongated styloid processes measuring more than $43.41 \mathrm{~mm}$ on either side. It is thus evident that the highest standard deviation among those aged over 45 years was related to measurements that were much longer than the mean.

Table 2 shows a comparison of styloid process lengths according to gender. As seen, men generally had longer right and left styloid processes than women. However, this difference was not statistically significant. The table also shows that the standard deviation for styloid process length was greater for men, thus suggesting that the absolute values varied more from the mean.

Table 2. Mean length of temporal styloid processes according to gender.

\begin{tabular}{ccccc}
\hline $\begin{array}{l}\text { emporal styloid } \\
\text { process length }(\mathrm{mm})\end{array}$ & Males & Gender & -Value & (T-Test) \\
\hline Right side & $33.34 \pm 8.92$ & $31.27 \pm 6.64$ & $32.00 \pm 7.27$ & 0.4153 \\
Left side & $33.69 \pm 8.34$ & $31.07 \pm 6.88$ & $31.75 \pm 7.62$ & 0.7288 \\
\hline
\end{tabular}

*Statistical significance. Source: Authors.

Among men, we also found that 29 of the 151 total evaluated right-side styloid processes were longer than $43.58 \mathrm{~mm}$ (19.2\%), while 21 of the 151 left-side styloid processes were longer than $44.97 \mathrm{~mm}$ (13.9\%). Among women, however, only 23 of 
the 352 total evaluated right-side styloid processes were longer than $43.39 \mathrm{~mm}$ (6.5\%), while only 22 of the 352 left-side styloid processes were longer than $42.47 \mathrm{~mm}(6.2 \%)$. This indicated that the standard deviation was higher among males due to a higher prevalence of styloid processes that were longer than the mean.

Elongated styloid processes of the temporal bone were also more common in men (Table 3). While 56.3\% and 56.9\% of male patients had elongated right and left styloid processes, respectively, female patients were only at $40.6 \%$ and $42.9 \%$ for these conditions, respectively. Further, these differences were statistically significant (Table 3). Regardless of side or gender, the overall prevalence of elongated styloid processes was $46.2 \%$.

Table 3. Prevalence of elongated styloid process.

\begin{tabular}{ccccc}
\hline $\begin{array}{c}\text { Prevalence of elongated } \\
\text { styloid process }\end{array}$ & Elongated & Normal length & Total & p-Value ( chi-square) \\
\hline Right side (males) & $85(56.3 \%)$ & $66(43.7 \%)$ & $151(100 \%)$ & $0.001705^{*}$ \\
Right side (females) & $143(40.6 \%)$ & $209(59.4 \%)$ & $352(100 \%)$ & $0.001216^{*}$ \\
Left side (males) & $86(56.9 \%)$ & $65(43.1 \%)$ & $151(100 \%)$ & $0.003796^{*}$ \\
Left side (females) & $151(42.9 \%)$ & $201(57.1 \%)$ & $352(100 \%)$ & $0.005156^{*}$ \\
\hline
\end{tabular}

*Statistical significance. Source: Authors.

\section{Discussion}

Eagle syndrome is classified into two distinct categories (i.e., classical and carotid). While the classical type is associated with symptoms such as facial pain, chronic cervicalgia, dysphagia, tinnitus, referred pain in the ear, glossopharyngeal neuralgia, and both orbital and irradiated pain in maxillary regions during swallowing and head rotation (Bruno et al., 2017; Alzarea et al., 2017; Pokhael et al., 2013), the carotid type occurs when the styloid process crushes the carotid arterial system, thus leading to dizziness, migraine, and possible stroke if compression of the carotid artery is too intense (Vodagaonkar et al., 2015).

Such clinical variations may result from anatomical changes to the styloid process, including those affecting shapes, lengths, and angles that contribute to nervous and vascular compressions (Bruno et al., 2019). The lateral wall of the larynx is affected in cases of medial angulation, thus causing recurring pain, dysphagia, and feelings of foreign bodies in the throat. On the other hand, lateral angulation may cause painful symptoms due to compression of the cranial nerves (Ekici et al., 2013; Natsis et al., 2014). As such, angulation is equally as important as length when examined as a clinical feature. However, it is not possible to analyze angulation using digital panoramic radiographs; indeed, this is a general deficiency of such a two-dimensional examination. It is therefore necessary for future studies to use three-dimensional examination tools in this regard (e.g., cone-beam computed tomography that allows examinations beyond length, including angulation and relationships with other anatomical structures of the styloid process) (Bruno et al., 2019).

There is currently no clear evidence about the causes of styloid process elongation that results in Eagle syndrome. However, there are several related theories (e.g., congenital styloid process elongation, calcification of the stylohyoid ligament through an unknown mechanism, and even bone tissue growth where the stylohyoid ligament inserts into the styloid process) (Vodagaonkar et al., 2015; Custódio et al., 2016). The most widely accepted suggestion is the congenital theory, which states that mechanical stressors during prenatal life cause elongation of the second branchial arch, thus leading to elongation of the styloid process (Vodagaonkar et al., 2015). Regardless, changes in the styloid process length and its stylohyoid chain complex are of anatomical, anthropological, and clinical importance (Natsis et al., 2014; Sudbakara et al., 2013). Several epidemiological surveys have demonstrated high variability in this context (Alzarea et al., 2017; Gracco el al., 2017; Vodagaonkar et al., 2015; Shayganfar et al., 2018) indeed, many have directly searched for relationships between age, gender, and styloid process elongation (Bruno et 
al.,2017; Alzarea et al.,2017; Sudbakara et al., 2013; Shayganfar et al., 2018; Alok et al., 2017). In this study, only right-side styloid process lengths increased with age, except when comparing patients between 31 and 45 years of age with those above 45 . Importantly, these differences were only statistically significant in regard to the right styloid process (the same was not found for the left side) (Table 1).

While this study's findings add to the current literature, results are still highly variable. On one hand, our results corroborate with several studies that reported a significant relationship between age and styloid process elongation (Bruno $\mathrm{G}$ et al.,2017; Alzarea et al.,2017; Alok et al., 2017;Skaik et al., 2013; Vieira et al., 2015). Further, a survey conducted among a Greek population demonstrated that styloid process length increased with age; however, no statistical significance was found (Custódio et al., 2016). On the other hand, many studies have indicated there is no relationship between age and styloid process elongation (Sudbakara et al., 2013; Shayganfar et al., 2018; Oztunç et al., 2014; Cullu et al., 2013). We suggest that this lack of consensus may be due to variations in different ethnic populations.

This study also diversified its results by specifically considering gender. While male subjects presented greater styloid processes lengths than females for both sides, these findings were not statistically significant in regard to any specific relationship between gender and styloid process length (Table 2). Although this coincides with several studies that also reported no such relationship (Bruno et al., 2017; Custódio et al., 2016; Sudbakara et al., 2013; Alok et al., 2017; Vieira et al., 2015; Oztunç et al., 2014), other studies have suggested that gender directly influences styloid process lengths for men (Alzarea et al., 2017; Ekici et al., 2013; Shayganfar et al., 2018; Skaik et al., 2013; Cullu et al., 2013). Further, a study performed among Eagle syndrome patients found significant differences between genders; that is, female subjects had longer styloid processes than male subjects (Pokhael et al., 2013). This finding may be the result of sample allocation, however, as all other studies cited here recruited participants from the general population rather than focusing on those with Eagle syndrome.

In this study, $46.2 \%$ of all subjects had elongated styloid processes. Again, there are large discrepancies in the literature, with results varying from $4.5 \%$ to $67 \%$ of all subjects when only including articles published within the current decade (Alzarea et al., 2017; Gracco, 2017; Vodagaonkar et al., 2015; Natsis et al., 2014; Custódio et al., 2016; Sudbakara et al., 2013; Alok et al., 2017; Vieira et al., 2015; Oztunç et al., 2014; Cullu et al., 2013: Asrani and More, 2010; De Andrade et al., 2012). Such a high degree of variability may also be due to ethnic differences ${ }^{8}$. For instance, the compared data were obtained from many diverse areas, including India (Sudbakara et al., 2013), Saudi Arabia (Alzarea et al., 2017), Italy (Gracco A et al., 2017), Greece (Natsis et al., 2014), and Brazil (Alok et al., 2017). In fact, this study's findings are most similar to those from a previous Brazilian study, which found that $43.9 \%$ of all subjects had elongated styloid processes.

Such vast differences may also be due to study sample allocations and/or data acquisition methods (Bruno G et al., 2019). For instance, some studies have randomly included individuals from entire populations (Bruno et al., 2017; Vadagaonkar et al., 2015; Shayganfar et al., 2018; Alok et al., 2017), while others have focused on subjects with Eagle syndrome (Pokhael et al., 2013), those diagnosed with temporomandibular disorders (De Andrade et al., 2012), and even subjects of advanced age (Alzarea et al., 2017).

Eagle syndrome should not be diagnosed as trigeminal neuralgia. These conditions can easily be differentiated through a careful analysis of pain history; Eagle syndrome entails persistent pain, while trigeminal neuralgia entails intermittent symptoms (Vadagaonkar et al., 2015). Further, light touch in the tonsillar area exacerbates pain, which can be alleviated through local anesthesia. This observation therefore aids in the diagnostic process ${ }^{9}$. Further, some patients with pain in the head and neck attempt to find solutions at dental offices, where dentists can diagnose Eagle syndrome and refer them to an otorhinolaryngologist (Bodin et al., 2013) who can either non-surgically (e.g., drug therapy with corticoids) or surgically treat the condition (Bruno et al., 2017; Vieira et al., 2015).

Some reports have found cases in which patients with histories of stroke have acute facial weakness and mixed aphasia, 
which can be diagnosed with internal carotid artery dissection and/or complete occlusion associated with acute heart attack due to the presence of elongated styloid processes (Dewan et al., 2016; Jelodar et al., 2018; Ozura et al., 2014). There have also cases in which facial paralysis develops after dissection of the carotid artery due to styloid process lengths measuring $54.7 \mathrm{~mm}$ in the left side and $59.2 \mathrm{~mm}$ in the right (Dewan et al., 2016).

Further, one study used magnetic resonance imaging (MRI) to find infarct regions in the brain hemispheres and reduced flow through the internal carotid and medial cerebral arteries caused by styloid process lengths of $41.9 \mathrm{~mm}$ and $36.8 \mathrm{~mm}$ in right and left sides, respectively (Ozura et al., 2014). The same study reported another case of paralysis involving the left sagittal half, which manifested as limited function on the opposite side of the cerebrovascular accident. This case was also associated with an elongated styloid process (34.3mm) (Ozura et al., 2014).

Atheroma plaques, which are fibrous fatty plaques attached to arterial walls, also increase the risk of cerebrovascular accidents and heart attacks. Knowing this, some studies have shown a significant relationship between atheroma plaques and styloid process elongation, thus indicating that patients with elongated styloid processes have higher risks of experiencing cerebrovascular accidents (Hamedani et al., 2015). The same study also showed that patients with low bone density and styloid process elongation needed vascular assessment to determine whether they were at high risk of developing atheroma plaques (Ozura et al., 2014). The evidence indicates that styloid process lengths varying from $34.3 \mathrm{~mm}$ to $59 \mathrm{~mm}$ can result in serious vascular conditions (i.e., when associated with other risk factors, such as atheroma plaques and low bone density) with several associated morbidities (e.g., cerebral paralysis and other deadly functional deficiencies) (Dewan et al., 2016; Jelodar et al., 2018; Ozura et al., 2014). Notably, this study found that $26.3 \%$ of all analyzed styloid processes were longer than $34.3 \mathrm{~mm}$, this being the measurement where associations with vascular conditions begin to present. These subjects require additional evaluations to determine whether they are at risk of cerebrovascular accidents, which may be associated with atheroma plaques, elongated styloid processes, and even osteoporosis.

In the above context, the definitive treatment involves surgically shortening the styloid process. There are two surgical approaches in this regard. The first is the intraoral approach, which is advantageous due to its relative simplicity, less needed time, and absence of resulting visible scars. However, visualization is limited during this procedure, which thus presents higher risks of neurovascular lesions and deep cervical infections. The second is the extraoral approach, which provides a more satisfactory and wider surgical field and is also associated with fewer infections; however, the procedure results in scarring and other aesthetic issues (Ekici et al., 2013; Vieira et al., 2015).

Length, position, angle, and the distance between styloid processes are important clinical data for use among neurologists, neurosurgeons, radiologists, maxillofacial surgeons, and otorhinolaryngologists. Indeed, this region houses important structures of the neck, including cranial nerves, the larynx, esophagus, arteries, and veinsn (Bruno G et al., 2017; Ekici et al., 2013; Vieira et al., 2015). In addition to using panoramic radiographs, it is thus important to evaluate styloid process lengths through computed tomographic methods. These can also be used to assess styloid process angulations in syndromic patients, thereby establishing the relationship between angulation and Eagle syndrome (Pokhael et al., 2013; Natsis et al., 2014).

\section{Conclusion}

This study's examination in the State of Ceará, Brazil found that $46.2 \%$ of all subjects exhibited elongated styloid processes based on respective panoramic radiographs. However, no relationship was found between styloid process length and gender. On the other hand, male subjects presented a higher prevalence of styloid process elongation than female subjects. Further, the relationship between styloid process length and age was only significant when considering the right side. Notably, patients over 45 years of age presented elongated left styloid processes, while those who were 31-45 showed right side elongations. Based on these results, we highlight the importance of evaluating the styloid process using panoramic radiographs as 
a complimentary measure for diagnosing syndromic patients. However, it is also necessary for future studies to use threedimensional examination tools (e.g., cone-beam computed tomographic methods) that allow researchers to study elements other than length, including angulation and any relationships with anatomical structures of the styloid process.

\section{References}

Alok, A., Singh, I., \& Singh, S. (2016). Evaluation of styloid process in Bareilly population on digital panoramic radiographs. Journal of Indian Academy of Oral Medicine and Radiology, 28(4), 381. https://doi.org/10.4103/0972-1363.200623

Alzarea, B. K. (2017). Prevalence and pattern of the elongated styloid process among geriatric patients in Saudi Arabia. Clinical Interventions in Aging, 12, 611617. https://doi.org/10.2147/CIA.S129818

Bodin, C., Ph, D., Lenarda, R. Di, \& Sc, M. (2013). Eagle ’s Syndrome : Signs and Symptoms.

Bruno, G., de Stefani, A., Balasso, P., Mazzoleni, S., \& Gracco, A. (2017). Elongated styloid process: An epidemiological study on digital panoramic radiographs. Journal of Clinical and Experimental Dentistry, 9(12), e1446-e1452. https://doi.org/10.4317/jced.54370

Bruno, G., De Stefani, A., Barone, M., Costa, G., Saccomanno, S., \& Gracco, A. (2019). The validity of panoramic radiograph as a diagnostic method for elongated styloid process: A systematic review. Cranio ${ }^{\circledR}, 00(00), 1-8$. https://doi.org/10.1080/08869634.2019.1665228

Cullu, N., Deveer, M., Sahan, M., Tetiker, H., \& Yilmaz, M. (2013). Radiological evaluation of the styloid process length in the normal population. Folia Morphologica (Poland), 72(4), 318-321. https://doi.org/10.5603/FM.2013.0053

Custodio, A. L. N., Silva, M. R. M. A., Abreu, M. H., Araújo, L. R. A., \& Oliveira, L. J. De. (2016). Styloid Process of the Temporal Bone: Morphometric Analysis and Clinical Implications. BioMed Research International, 2016. https://doi.org/10.1155/2016/8792725

de Andrade, K. M., Rodrigues, C. A., Watanabe, P. C. A., \& Mazzetto, M. O. (2012). Styloid process elongation and calcification in subjects with TMD: Clinical and radiographic aspects. Brazilian Dental Journal, 23(4), 443-450. https://doi.org/10.1590/S0103-64402012000400023

Dewan, M. C., Morone, P. J., Zuckerman, S. L., Mummareddy, N., Ghiassi, M., \& Ghiassi, M. (2016). Paradoxical ischemia in bilateral Eagle syndrome: A case of false-localization from carotid compression. Clinical Neurology and Neurosurgery, 141, 30-32. https://doi.org/10.1016/j.clineuro.2015.12.004

Ekici, F., Tekbas, G., Hamidi, C., Onder, H., Goya, C., Cetincakmak, M. G., Gumus, H., Uyar, A., \& Bilici, A. (2013). The distribution of stylohyoid chain anatomic variations by age groups and gender: An analysis using MDCT. European Archives of Oto-Rhino-Laryngology, 270(5), 1715-1720. https://doi.org/10.1007/s00405-012-2202-5

Estrela, C (2018). Metodologia científica: ciência, Ensino, pesquisa. 3 ed. Porto Alegre-RS: Artes Médicas, v. 1. 707p.

Feldman, V. B. (2003). Eagle's syndrome: a case of symptomatic calcification of the stylohyoid ligaments. The Journal of the Canadian Chiropractic Association, $47(1), 21$.

Gracco, A., Stefani, A. De, Bruno, G., Balasso, P., Alessandri-Bonetti, G., \& Stellini, E. (2017). Elongated styloid process evaluation on digital panoramic radiograph in a North Italian population. Journal of Clinical and Experimental Dentistry, 9(3), e400-e404. https://doi.org/10.4317/jced.53450

Hamedani, S., Dabbaghmanesh, M. H., Zare, Z., Hasani, M., Torabi Ardakani, M., Hasani, M., \& Shahidi, S. (2015). Relationship of elongated styloid process in digital panoramic radiography with carotid intima thickness and carotid atheroma in Doppler ultrasonography in osteoporotic females. Journal of Dentistry (Shiraz, Iran), 16(2), 93-939

Jelodar, S., Ghadirian, H., Ketabchi, M., Ahmadi Karvigh, S., \& Alimohamadi, M. (2018). Bilateral Ischemic Stroke Due to Carotid Artery Compression by Abnormally Elongated Styloid Process at Both Sides: A Case Report. Journal of Stroke and Cerebrovascular Diseases, 27(6), e89-e91. https://doi.org/10.1016/j.jstrokecerebrovasdis.2017.12.018

More, C., \& Asrani, M. (2010). Evaluation of the styloid process on digital panoramic radiographs. Indian Journal of Radiology and Imaging, 20(4), 261-265. https://doi.org/10.4103/0971-3026.73537

Natsis, K., Repousi, E., Noussios, G., Papathanasiou, E., Apostolidis, S., \& Piagkou, M. (2014). The styloid process in a Greek population: an anatomical study with clinical implications. Anatomical Science International, 90(2), 67-74. https://doi.org/10.1007/s12565-014-0232-3

Ogura, T., Mineharu, Y., Todo, K., Kohara, N., \& Sakai, N. (2015). Carotid Artery Dissection Caused by an Elongated Styloid Process: Three Case Reports and Review of the Literature. NMC Case Report Journal, 2(1), 21-25. https://doi.org/10.2176/nmccrj.2014-0179

Öztunç, H., Evlice, B., Tatli, U., \& Evlice, A. (2014). Cone-beam computed tomographic evaluation of styloid process: A retrospective study of 208 patients with orofacial pain. Head and Face Medicine, 10(1), 1-7. https://doi.org/10.1186/1746-160X-10-5

Pereira A, Shitsuka D, Parreira F, Shitsuka R. Método Qualitativo, Quantitativo ou Quali-Quanti [Internet]. Metodologia da Pesquisa Científica. 2018. 119 p. Available from: https://repositorio.ufsm.br/bitstream/handle/1/15824/Lic Computacao Metodologia-Pesquisa-Cientifica.pdf?sequence=1. Acesso em: 28 março 2020

Pokharel, M., Karki, S., Shrestha, I., Shrestha, B. L., Khanal, K., \& Amatya, R. C. M. (2013). Clinicoradiologic evaluation of Eagle's syndrome and its management. Kathmandu University Medical Journal, 11(44), 305-309. https://doi.org/10.3126/kumj.v11i4.12527 
Research, Society and Development, v. 10, n. 8, e1210817026, 2021

(CC BY 4.0) | ISSN 2525-3409 | DOI: http://dx.doi.org/10.33448/rsd-v10i8.17026

Scaf, G., Freitas, D. Q. de, \& Loffredo, L. de C. M. (2003). Diagnostic reproducibility of the elongated styloid process. Journal of Applied Oral Science, 11 (2), 120-124. https://doi.org/10.1590/s1678-77572003000200007

Shaik, M. A., Naheeda, Kaleem, S. M., Wahab, A., \& Hameed, S. (2013). Prevalence of elongated styloid process in Saudi population of Aseer region. European journal of dentistry, 7(4), 449-454. https://doi.org/10.4103/1305-7456.120687

Shayganfar, A., Golbidi, D., Yahay, M., Nouri, S., \& Sirus, S. (2018). Radiological Evaluation of the Styloid Process Length Using 64-row Multidetector Computed Tomography Scan. Advanced Biomedical Research, 7(1), 85. https://doi.org/10.4103/2277-9175.233479

Sudhakara Reddy, R., Sai Kiran, C., Sai Madhavi, N., Raghavendra, M. N., \& Satish, A. (2013). Prevalence of elongation and calcification patterns of elongated styloid process in South India. Journal of Clinical and Experimental Dentistry, 5(1), 30-35. https://doi.org/10.4317/jced.50981

Vadgaonkar, R., Murlimanju, B. V., Prabhu, L. V., Rai, R., Pai, M. M., Tonse, M., \& Jiji, P. J. (2015). Morphological study of styloid process of the temporal bone and its clinical implications. Anatomy and Cell Biology, 48(3), 195-200. https://doi.org/10.5115/acb.2015.48.3.195

Vieira, E. M. M., Guedes, O. A., De Morais, S., De Musis, C. R., Albuquerque, P. A. A., \& Borges, Á. H. (2015). Prevalence of elongated styloid process in a central brazilian population. Journal of Clinical and Diagnostic Research, 9(9), 90-92. https://doi.org/10.7860/JCDR/2015/14599.6567 